\title{
14. Reconciliation without history: state crime and state punishment in Chile and Australia
}

\author{
PETER READ
}

Chile in the 1990s struggled to confront the brutal oppression of the left during the Pinochet years (1973-1990). In the same period, Australia struggled to confront the brutal persecution of its Indigenous minority, especially the Stolen Generations (1788-1970s). My paper asks: did the enquiries into state repression by the two nations encourage or impede national understandings of their pasts? Did they lead to national reconciliation? Do we expect too much of Truth and Reconciliation Commissions?

\section{Re-establishing the republic after state violence: the via Chilena}

The psychologist Elizabeth Lira and the political scientist Brian Loveman examined a number of formal and informal strategies developed in Chile over two centuries to re-stabilise the nation after a period of state violence, a set of procedures for reconciliation after political cataclysm. The measures are partly constitutional, partly informal, but each helps to allow the government, and the nation, to function again with the approval of a majority of its citizens. The measures include commutation of prison sentences for crimes committed by police and military, the return of exiles sometimes with restitution of property or pension, one-off payments to sufferers on both sides of the recent conflict, and special laws for named individuals for purposes of reparation, and symbolic measures like public memorials. They also include the creation of new political coalitions involving some of the losers in the conflict, redefinition of key actors, parties and worker organisations to carry on under new names, re-incorporation of some of the politically defeated into cabinet, universities or bureaucracy, and constitutional and legal reforms to ratify the re-establishment of the 'Chilean family'. Though few Chileans surviving a coup d'etat or revolution believed that political forgetting was possible, Chileans held it to be necessary periodically to 'start again'. Such attempted reconciliation did not necessarily 
signify forgiveness, more that certain violent measures taken by the state in a period of crisis were not later to be openly discussed. Measures of reconciliation demanded that officials of a new political regime avert their gaze from certain events; citizens who refused to do so were held to be in bad taste, or worse. Lira and Loveman argue that such measures have been to a point enacted by postPinochet left-centre governments as well as in earlier periods. ${ }^{1}$

A key element of this strategy for national survival, then, was what was left unsaid. Two Chilean Commissions, known as the Rettig and the Valech Reports, examined the violence of the Pinochet period. ${ }^{2}$ Neither achieved what its supporters hoped for: Rettig examined the history of the political assassinations and the disappeared, Valech the experiences of the tortured. Neither investigated the circumstances leading to Pinochet's coup of September 1973 in any detail. Neither named any but a very few of the perpetrators or violators of human rights, nor discussed the wider historical context in which these events took place. Critics noted similarities with other recent Latin American enquiries into state violence. Argentina's and Guatemala's showed an implied preference for catharsis and forgiveness over punishment. ${ }^{3}$ All tended towards the story rather than the explanation, the narrative rather than the forensic. They affirmed as truth the testimony of the victims. They presented history less as a collective conflict of interests or ideas, more as violations of individual human rights beyond the constitutional or legal laws of each country. Resistance, especially collective resistance, was not a major theme of any of the reports. Each tended to avoid the deep structural, racist or economic issues that had led to the violence. They largely eschewed naming any guilty individuals or political parties. They did not explicitly require subsequent governments to exact any punishment except - if the government chose - against a few named individuals. In this way, the privileging and validating of the individual experience of trauma and healing had turned the focus away from the inequities of the social structure.

Despite the non-punitive nature of the recommendations, the Guatemalan and Argentinean governments distanced themselves from the final reports, while for successive centre-left Chilean governments the powerful military has been

1 Lira and Loveman 2007: 42-76.

2 The Rettig Report, or the 'Report of the National Commission for Truth and Reconciliation': 'Rettig Report', Wikipedia, <http://en.wikipedia.org/wiki/Rettig_Report>; Valech: National Commission on Political Imprisonment and Torture Report, 2004, 'Valech Report', Wikipedia, <http://en.wikipedia.org/wiki/Valech> 3 The editors of the 2007 special edition of Radical History Review criticised Memory of Silence, the 12-volume Guatemalan Report of 1991 which followed 34 years of internal conflict and 200,000 dead, for narrowing the narratives through which the past is understood. The editorial claimed that the Report merely individualised violations of human rights and neglected to identify victims also as social actors or activists for social change. Grandin and Klubock 2007: 3-7. 
a constant reminder that the internal stability of the country depends on its continuing good will. Pinochet supporters have always maintained that they did nothing wrong: they merely saved the republic from the cancer of communism. ${ }^{4}$

The Chilean people have developed a strategy for punishing those whom the state refuses to name but whose identity is public knowledge. As long as the Chilean state declines to punish the murderers and torturers of the Pinochet regime, runs the popular reasoning, then the people will have to do it. This public spectacle is known as the funa, a public denunciation of a former official of the regime who has so far remained unpunished.

The funa occurs outside the home or workplace of the accused. In preparation for each such denunciation, the 'Funa Commission of Chile' posts on the web the chosen starting-point, usually a street corner. The exact destination, however, is not divulged. The crowd - it may be 50, it may be many hundreds - assembles with placards, flags and loudhailers. At this point, the destination, perhaps 20 minutes march away, is now revealed. The procession begins. Marching, or ambling, to the dwelling or workplace, the leader shouts

Si no hay justicia... [If there is no justice...]

And the crowd roars in response

Hay funa! [There is funa]

While the invocation literally translates 'If there is no justice, there is funa' it carries the deeper implication that 'for as long as there is no justice carried out by the state, then there is the funa of the people'. Arrived and assembled, the crowd joins in the public denunciation of the named killer or torturer, whom the Chileans call the 'condenado', the 'condemned'. The funa concluded, the participants then disperse. ${ }^{5}$

Such a conclusion may seem rather anti-climactic, but granted the limitations in which successive post-Pinochet Chilean governments move (or choose to move) against notorious Pinochet officials, the funa is grounded in a sound sense of the possible. Only a handful of very senior Pinochet officials have been prosecuted and imprisoned by a government whose formal investigations have worked very energetically to name the victims and their sufferings, but refused to move against all but a very few of the most infamous perpetrators.

Funa originated in Argentina, and first were led by the survivors or close family of the disappeared. Some lasted for a week, the 'funistas' camping outside the dwelling. Argentineans sometimes describe the Chilean version, some of which

4 Read and Wyndham 2008: 81.

5 For a detailed description of a funa of lesser importance, see Read 2009: 45-51. 
last not much more than an hour, as feeble in comparison. Yet some funa are not without danger for the participants. Any major funa in the Santiago central business district will be closely observed by busloads of police, water cannon and tear gas ready. In August 2007 an Argentinean cameraman covering a funa was arrested for 'public disorder', and only released on a promise to leave the country. ${ }^{6}$

Like the measures identified by Lira and Loveman, the funa is, perhaps, useful for everyone - the left, the government and the armed forces of the right. The revolutionary Chilean left, once so strong, is now disunited and has nowhere to go. At funa, the crowd sings the Internationale, condemns the United States' government for its imprisonment of Cuban political prisoners, and applauds speeches in praise of Chavez. Much fury is expressed over the Bachelet government's social policies, its failure to name the perpetrators of state violence, and its handling of Indigenous issues. The military itself may find the funa useful. Since Pinochet's death, and as younger officers continue to assume the higher commands, an attitude may be developing that from now on the old guard will have to look after itself, provided that the army itself is not humiliated by state-driven public trials and prison sentences.

The huge and passionate funa of the killer of Victor Jara shows how far angry Chileans are prepared to usurp the role of the state to punish individuals irrespective of official enquiries. A popular left-activist singer-song writer enjoying something of the status and position of Pete Seeger, Jara was killed in the first days after the coup. Ignoring his family's pleas, he insisted on attending what was to have been a function led by Allende at the Technological University of the State on the 11 September 1973. Next day with hundreds of others he was arrested and taken to Estadio Chile - now the Victor Jara Stadium - where he was recognised by a tall, blond Chilean known as 'el principe', the prince, who reportedly said, 'This one's for me'. Jara was horribly tortured, especially by el principe, for several days before being murdered. But it was not until 2006 that el principe was identified as Dimter Bianchi, 'mad Dimter', a senior bureaucrat of a government department working in the Central Business District of Santiago. A massive funa was arranged. Such were the grief and fury of the funistas (the people who carry out the funa) on that day that the film of the Funa of Victor Jara can still reduce an audience to shocked silence. ${ }^{7}$

Early in the video, we see the planning taking place, including the crucial question of who amongst the funistas will enter the building to ascend to the high-level office where Bianchi will be at work. The procession begins. Camera

6 Ernesto Carmona, 'Detención illegal de documentistas en Chile', Argentina Centro de Medios Independientes, 23 August 2007, <http://argentina.indymedia.org/news/2007/08/541832.php>

7 The Funa of Victor Jara 2007. Excerpts can be seen on YouTube under this title. 
following, some 20 people push their way through. They form a crush so tight that the leader of the funa, designated to carry out the formal accusation, cannot squeeze in. He ascends his podium in the passage outside to begin his formal, ten-minute denunciation. Those inside the office surround and jostle Bianchi. Amidst the uproar of shouts and execrations, we see Bianchi at his desk, trying to rise. Perhaps in the commotion, the camera is bumped or loses focus for a few seconds, for next we see him still in his neat trousers, white shirt and tie, now lying on his back on his desk, legs waving in the air like a cockroach. Everywhere the funistas are screaming or brandishing huge photographs of Jara. Bianchi tries to shield his face from the faces and the cameras with his arms and hands. In panic, he seizes the nearest poster that a protester is pushing into his face. It is a huge photograph of his victim centimetres from his nose. Someone pushes open the window, possibly to allow the huge crowd waiting below to hear the commotion. Above the tumult, outside in the passageway, another camera follows the cantor calmly reading the official denunciation. No one can hear a word. After 20 minutes the funistas leave the building and the cantor, now mounted on his ground-level ladder, repeats the denunciation through a megaphone to the people outside who, their texts at the ready, follow and recite the denunciation word by word. We can now understand better, in the light of the via chilena, how el principe happened to be working as a senior government bureaucrat in 2000, and, equally, why the crowd was so enraged that Bianchi had not been punished by the state. Of Jara's murder the state enquiries to this point had said very little.

In the widest sense, funa may represent a trend in the western world towards civil governance, in which 'the people' act in the name of human rights wherever government is perceived to be quiescent or unwilling. Whistle-blowers, local citizenry and investigative reporters converge on the belief that the defence of human rights is no longer a state responsibility alone. Indeed, a democratic state may sometimes oppose the exercise of certain rights, and for a variety of reasons. The funa too is a recognition that in modern civil society justice must sometimes be administered in many forms and by several interest groups, even by individuals. But as we shall see, funa is practised best by those citizens whose political culture has prepared them to expect state violence, and state denials of that violence, and to take their own measures of retribution beneath the shadow of military power.

Little by little, we are inching towards setting Australians' confrontation with their own violent past against the events of the South American dictatorship. For while Chileans since 1990 were confronting the executions, tortures and disappearances of the 17 years of Pinochet terror, Australians were grappling with understanding the long persecution of Indigenous people. Indeed, the similarities between the history of these Truth and Reconciliation Commissions, 
and Australia's recent enquiries are intriguing. The Australian equivalents of the Rettig and Valech Reports were the 1993 Royal Commission into Aboriginal Deaths in Custody, the 1990 Enquiry into the Stolen Generations Bringing Them Home and the Final Report of the Council for Aboriginal Reconciliation. ${ }^{8}$

First was the 1987 Royal Commission into Aboriginal Deaths in Custody. The Commission investigated 99 cases of Aboriginal prison or institutional deaths over a ten year period, the individual findings of which were published in separate, and often horrifying, reports. The major five volume findings included recommending fundamental changes in official procedures from prison design to arrest procedures, but no recommendations for further judicial inquiries into the behaviour of individuals. ${ }^{9}$ Bringing Them Home, the so-called 'Stolen Children' Report of 1997, was carried out by the national Human Rights and Equal Opportunity Commission under a small budget. It took an enormous quantity of mainly oral evidence about how and why the children were removed and their subsequent history in institutions or private homes. The Enquiry produced important recommendations, but again called for no prosecutions. The Council for Aboriginal Reconciliation, established in 1990, received a tenyear brief to present its Recommendations as to how the nation might best reconcile with its Indigenous people. It consisted of some 30 members, half of them Indigenous, and was led throughout its life by an Indigenous Chairperson and a non-Indigenous Vice-Chairperson. While theoretically independent, its meetings were monitored by a government observer, and its funding remained in government hands. It presented its Final Report and Blueprint for the Future at a huge ceremony at the Sydney Opera House in May 2000. While not specifically enjoined to investigate the past, clearly the Council was predicated on the need to ameliorate the historically bad relations between invaders and invaded.

It may be wondered, given the different purposes and methodologies of each, to what extent the three Commissions can be seen as forming a national soulsearching. While it is true that each followed different procedures, the most persuasive consideration is that each addressed historic violence against Aboriginal people over a short or long period. Each was commissioned by less conservative governments after public pressure to reassess a violent past against an identified minority section of the population, and to provide blueprints for the

8 Aboriginal Deaths in Custody. The Royal Commission and its Records, <http://www.naa.gov.au/ naaresources/Publications/research_guides/pdf/black_deaths.pdf >; Bringing Them Home, The Stolen Children's Report (1997), <http://www.hreoc.gov.au/social_justice/bth_report/index.html>

9 The Royal Commission produced a number of reports, including individual reports for each death investigated. These were presented separately as they were completed. The Commission also produced an Interim Report, which was presented on 21 December 1988. The final report, signed on 15 April 1991, made 339 recommendations, mainly concerned with procedures for persons in custody, liaison with Aboriginal groups, police education and improved accessibility to information. Many of the reports are available at: $<$ http://www.austlii.edu.au/au/other/IndigLRes/rciadic/> 
future. Each made Final Reports within the same decades as the Latin American experiences. Each set of Commissioners had to decide how to balance individual rights with collective rights, what weight to give to international protocols of human rights, how much to investigate patterns of abuse rather than a series of specific events, how much, in the perceived national interest, to weigh an exposition of past evil against a program of future reform. Though some states had conducted their own inquiries into specific allegations of wrongdoing, the national commissions of the 1980s and 1990s may be said to have been brought about by pressure from informed and articulate general criticism of both policies and bureaucratic action. Like Chile's 'Rettig Report', neither the Royal Commission into Black Deaths in Custody nor the Bringing Them Home Commissioners recommended prosecutions against any individuals responsible for policy decisions or criminal acts. The fate of all three, so disappointing to their proponents in terms of government response, together form an argument that the three Enquiries were the nearest Australia was able to come, or likely ever to come, to a Truth and Reconciliation Commission into its own historic past.

Again we may pause to ask, granted that the three Australian Enquiries can in some senses be placed together, in what ways are they comparable to investigations into the Pinochet regime. There may indeed be closer analogies. Children of Argentinean 'subversive' parents, for instance, were much more specifically targeted by the military junta than Chile's. ${ }^{10}$ Clearly, there were obvious differences between officials removing Aboriginal children and Pinochet's secret police torturing and killing Chilean leftists. On the other hand, I am here discussing the role of the state, not its agents, and the malevolent attitude of state governments intent on putting an end to the childrens' Aboriginality for over 100 years is the point at issue, not the individual motives that certain well meaning officials may have had. While comparisons of absolute numbers of deaths and instances of great cruelty between any two nations can be distracting, the violence inflicted upon Aboriginals on the frontier, and later by the police, and the administrative violence visited upon adults on reserves and children in institutions, seem to me to be comparable with the Chilean experience. Surely, it was this awareness of very deep injustices that caused the Labor government to establish the Council for Aboriginal Reconciliation.

Valech's naming of the 30,000 individual tortured Chileans achieved some senses of recognition and validation of the victims' experience. Especially in the context of Bringing Them Home, we may ask - was the unearthing of the story of the stolen children cathartic, traumatic, painful or healing for the victims? The consensus seems to be, broadly, healing. Did exploring and presenting some

10 The enforced adoptions, sometimes like Australia's policies, were intended to re-socialise the children of murdered mothers by 'responsible' elements of society; see Arditti 1991: 1. 
historical truths achieve the national reconciliation that it has failed to do in Chile? I would answer, for the stolen children themselves, yes, but for the wider issue of dispossession, no. To the Recommendations of the Royal Commission into Aboriginal Deaths in Custody the Labor government was sympathetic, but it implemented few of its recommendations. The succeeding conservative government of John Howard distanced itself decisively from Bringing Them Home first by refusing to apologise to the Stolen Generations, then acceding to very few of its 64 Recommendations. Howard stated 'I do not believe, and have always strongly rejected, notions of intergenerational guilt'. ${ }^{11}$

As we shall see, Howard did not have much sympathy either for the 2000 Final Report of the Council for Aboriginal Reconciliation.

An implied question for the members of the Council for Aboriginal Reconciliation was, like Chile's: to what extent is a reconciled future contingent upon the acknowledgement of an evil past? Or might such a presentation actually be counter-productive? Might a thorough, and therefore necessarily horrific, exposure of a national past actually work against building the metaphoric bridges that the Council for Aboriginal Reconciliation was recommending to the nation? In short, how much history is necessary, or desirable, for national reconciliation in the future? The answer to that question lies in the view of national history that is accepted by the population. Both the Reconciliation Council and the Black Deaths in Custody Commission avoided strong general condemnation of the national context in which historic evils had occurred. The Stolen Children enquiry labelled the removal policy 'genocide' and opened a hornet's nest. ${ }^{12}$

I propose, then, that apart from the more or less accepted narrative of the Stolen Generations, Australians still have no accepted public discourse of significant wrongdoing towards Aborigines. We may judge the force of my argument by considering the findings of the Canadian Royal Commission into its historical relationship with Indigenous people:

A careful reading of history shows that Canada was founded on a series of bargains with Aboriginal peoples - bargains this country has never fully honoured. Treaties between Aboriginal and non-Aboriginal governments were agreements to share the land. They were replaced by policies intended to

...remove Aboriginal people from their homelands

...suppress Aboriginal nations and their governments

11 Commonwealth Parliamentary Debates, House of Representatives, 30 October 1996: 6158; quoted in Goot and Rowse 2007: 141.

12 For instance, 'Sir Ronald Wilson Should Apologise', <http://www.ipe.net.au/nltr8.html> 
...undermine Aboriginal cultures

...stifle Aboriginal identity. ${ }^{13}$

\section{History and the Council for Aboriginal Reconciliation}

If the Chilean Commissioners thought it wiser to present just one side of the Pinochet oppression, what of the Reconciliation Council? In truth, while an important self-elected task for the Council was to inform the public, it did not produce much historical material in its ten-year existence. ${ }^{14}$ The public seemed to have remained resistant to what it did produce; indeed a whole generation of publications highly critical of settler and government actions, by historians, Indigenous autobiographers, and a mountain of oral history, seemed not to have made much difference outside universities and schools. ${ }^{15}$ The television personality and member of the Reconciliation Council Ray Martin recalled that on the very first Council meeting in 1990, each member explained their own life experiences: 'All the whitefellers walked away shocked - we thought, if only the rest of Australia could hear this' ${ }^{16}$ Michelle Grattan concluded from an unenthusiastic response that Australians found it too painful to see through the eyes of victims, to comprehend that their democracy had a serious flaw, that collective responsibility was hard to accept. Both the national education system and the folk culture had written the Indigenous people out of the national story. ${ }^{17}$ While Chileans knew far better what had happened to the Allende supporters, many justified their repression as a necessary preemptive strike against a Castrostyle dictatorship. Australians like Howard remained several misapprehensions behind, following a fairy-story of fundamentally peaceful interaction between invaders and invaded. Inga Clendinnen asked

Why construct a single, simple and therefore necessarily false tale and call it Australia's history? Why not a cornucopia of true stories that will tell us what really happened? Why deny the courage of the early settlers? ... What most surely unites Aborigines now - what leads them

13 Highlights from the Report of the Royal Commission on Aboriginal Peoples, <http://www.ainc-inac. gc.ca/ap/pubs/rpt/rpt-eng.asp\#chp3>

14 Only one of Council's 'Issues Papers' dealt specifically with history. The Issues were: Key Issues Papers; Understanding Country, Improving Relationships Valuing Cultures, Sharing History, Addressing Disadvantage, Responding To Custody Levels, Agreeing On A Document, Controlling Destinies, Addressing The Key Issues For Reconciliation; <http://www.austlii.edu.au/au/other/IndigLRes/car/pubs.html\#publish> 15 A reviewer of this paper queried whether I am underestimating the support for the idea of a critical history. I do not think so. Though clearly national perceptions have changed in relation to the stolen children, ethnic origins may play a significant part in perceptions about the original dispossession; I suspect also that historical knowledge is not always sufficiently distinguished by pollsters from opinion. In research amongst Australians of Greek, Ghanean and Chinese origin, especially, I found little sympathy for dispossession and a wider failure to link dispossession with national policy. See Read 1997: 87-96.

16 Ray Martin, quoted in Grattan 2000: 7.

17 Grattan 2000: 38 
to define themselves as Aborigines, whatever the percentage of blood is their shared historical experience of dispossession at the hands of the whites, and that is a history that we, who are their fellow citizens, know too little about. It happened, but we were looking the other way. They know it in their bones because it happened to their grandmothers, their uncle, their brother - because it happened to them. ${ }^{18}$

Clendinnen's powerful rhetoric perhaps put it too simply, but a visit to Reconciliation Place in Canberra shows how powerful was the drive of 'Reconciliation-without-history' in the Howard years. This site in the heart of the capital, extending over 100 metres, is described officially as 'a place which recognizes the importance of understanding the shared history of Indigenous and non-Indigenous Australians'. There is not much history to be seen, and very little of that is confrontational. Some of the monuments are simply wordless rock engravings, while others do not advance beyond 'feel-good' statements by Aboriginal elders such as Wenten Rubuntja: 'All of us have to live in this country, look after each other, share this country'. ${ }^{19}$ Amidst the platitudes, only one monument strikes a decisive dissonance. By far the strongest invocation of 'this is what really happened' (the wording of which does not appear on the Reconciliation Place website) is the Stolen Generations memorial. It is the only one actually planned by any of the victims of government policies, and the only one created independent of government monitoring. Its construction followed the public display of plans for a bowdlerised memorial to children deeply insulting to the memory of the victims of the separation policy. ${ }^{20}$ Its stern but heartfelt invocation resounds against the historical vacuity for what passes as 'Aboriginal reconciliation' in the rest of the memorials.

We the separated children of Australia would urge you to look through our eyes and walk in our footsteps, in order to understand our pain. We acknowledge all Australians to acknowledge the truth of our history to enable us to move forward together on our journey of healing because it is only the truth that will set us all free. ${ }^{21}$

Short on history as it may have been, the Reconciliation Council was by no means timid in its Blueprint for the Future. Its 2000 Final Declaration included the proposition 'Our nation must have the courage to own the truth, to heal the wounds of the past so that we can move on together with ourselves'.

18 Clendinnen 2000: 252-253.

19 National Capital Authority nd, <http://www.nationalcapital.gov.au/downloads/visiting/ reconciliation place/Reconciliation\%20Place_A_lasting_symbol_of_our_shared_journey.pdf>

20 The design implied the removal of Aboriginal children was merely another example of how children are socialised into an adult world. The memorial was constructed in defiance of strong Aboriginal disapproval and stands today adjacent to this second, 'counter-stolen generations memorial' quoting testimonies in strong condemnation of the policy of child removal. See Read 2007: 98-107.

21 'Stolen Generations', Memorial, Reconciliation Place, Canberra. 
Though the nature of the 'wounds' was not enunciated, the carefully-worded proposals included 'an agreement or treaty through which unresolved issues of reconciliation might be resolved'. ${ }^{22}$ It also courageously proposed, given the political climate, that one part of the nation should formally apologise and express 'its sorrow and sincere regret for the injustices of the past', while the other part accept 'the apologies and forgives'. ${ }^{23}$ Howard's government comprehensively rejected all of the six Proposals except number five, which dealt with measures of 'practical reconciliation'. He claimed that the government was already working hard on that.

Criticism from conservatives of the Declaration was expected, but some nonconservatives were unhappy that the Council did not go beyond broad nonspecifics like 'building bridges', at the cost of marginalising issues which did not fit, like sovereignty and land rights. Nor, perhaps by reasons of its funding, did the Council criticise the conservative position of the federal government. ${ }^{24}$ Nor were the proposals without Indigenous criticism. Heidi Norman found it 'extremely limiting and problematic' that reconciliation came to be linked with the Stolen Generations, and that 'sorry' came to be linked with them; 'the reconciliation movement had embraced the Stolen Generations not only in language but also as an over-riding understanding of Indigenous peoples' unjust treatment' ${ }^{25}$

Sovereignty and a treaty proposal were not the only casualties. Having 'the courage to own the truth' could mean everything - or nothing. Ready to trip any would-be reconciler was the stumbling block of history, as Aboriginal people understood it, and its relationship to natural, restorative or even transitional justice. The failed Joy Williams and the Cubillo and Gunner cases indicated that none of the perpetrators of acts of inhumanity against them would ever be punished, even after a 2007 Australian Court found for the first time that a removed Aboriginal child was entitled to compensation. ${ }^{26}$

22 Council for Aboriginal Reconciliation 2000, Final Report of the Council for Aboriginal Reconciliation, Recommendation 6, <http://www.austlii.edu.au/other/IndigLRes/car/2000/16/text10/htm >. The Council was of course well aware of the government's implacable opposition to a treaty.

23 Council for Aboriginal Reconciliation 2000, 'Australian Declaration Towards Reconciliation', <http:// austlii.edu.au/au/other/IndigLRes/car/2000/12/pg3.htm>

24 Gunstone 2005: 18-19.

25 Norman 2002: 13, 16. Heidi Norman had a point. Prime Minister Rudd's 'Apology' speech contained only two words about Aboriginal history generally before beginning on the main theme of separation: 'We reflect on their past mistreatment. We reflect in particular on the mistreatment of those who were stolen generations - this blemished chapter in our nation's history'; 'Rudd's apology to indigenous Australia', The Daily Telegraph, 12 February 2008.

26 The Bruce Trevorrow case: see Penelope Debelle and Jo Chandler, 'Stolen generation payout', The Age, 1 August 2007. The South Australian government proposes to appeal the amount of compensation, but not the factual findings of the Court. 
Does the truth, as the Stolen Generations memorial asserted, set us all free? Even if the world has agreed that there should be no more Nurembergs, then Truth Commissions that identify pain but not perpetrator, act but not issue, may lay false trails towards future reconciliation. The historian Mary Nolan, discussing Truth and Reconciliation Commissions generally, asked, what kinds of truth can such enquiries produce. Is truth justice - or is it an alternative to judges, forensic courts and punishments. ${ }^{27}$ What priority will Commissioners who are asked both to investigate the past, and to make recommendations about the future, allot to reparations to those injured, as it were, last year, compared to ameliorating the structural or attitudinal inequalities, of next year? At best, Truth Commissions may merely reduce the number of lies in circulation; they will never cleanse the nation. ${ }^{28}$

We can begin to see how the Bringing Them Home Commissioners, anxious to acknowledge past injustice, produced an official and (to some) irrefutable depiction of a terrible past, but one which perhaps necessarily depoliticised and decontextualised the historical circumstances and hence did not advance an understanding of the nation's history beyond cataloguing the types of abuse and identifying bad policy and cruel agents. By contrast historians well understand that the repression of Aboriginal people since 1788 may be explained in very wide contexts indeed - as a product of human nature, the imperatives of imperialism and colonialism, or the inevitable clash between agrarian and hunting economies. Other explanations might include the exigencies of an unyielding environment, the excesses of venture capitalism, masculinity, social elites, ideological movements, political parties, and, finally, of individuals acting malevolently on behalf of or independently of government. These all may be valuable contextual truths of one kind or another, but to an Aboriginal person the hard fact remains, 'My father was shot dead by a white man', or 'I was taken screaming from my mother, and put in a home and I have never recovered from the trauma. Why don't you admit that and say you're sorry?'

Herein lies the tricky nexus faced by all Truth and Reconciliation commissions, between doing justice to victims of great evil and the compiling of a wider history to which contextualising historians can assent. We can begin to see the utility of the via chilena, in enacting measures of individual and collective reparation without the state's necessary admitting why the measures are needed. Post-dictatorship Chile has achieved something close to what many had thought to be the minimum goal, that is, conciliation with neither reconciliation nor serious punishment of the guilty parties. The country is again governed by assent. Democracy of a kind has been restored. A few of the most notoriously guilty have been punished by one means or another. Most of the survivors and

27 Hayner 2002; Nolan 2007: 145-146.

28 Nolan 2007: 146. 
their families have received some kind of compensation. The ceremony of the funa also clearly belongs to those forms of 'people's reconciliation' which makes the victims of state violence, while not openly challenging state authority or disrupting public order very much, feel that they have exacted significant justice.

\section{A funa in Australia?}

Yet the kinds of truths to be uncovered, any proposed punishment, and any restitution to the injured, in the last resort depend on the political culture of a particular state. Howard's sentiments perhaps reflected those of the wider Australian nation when he said,

I do not believe it is accurate or fair to portray Australia's history since 1788 as little more than a disgraceful record of imperialism, exploitation and racism. Such a portrayal is a gross distortion and deliberately neglects the overall story of great Australian achievement that is there in our history to be told'. ${ }^{29}$

That is the political culture into which fell Bringing Them Home and the Reconciliation Council's Australian Declaration Towards Reconciliation. ${ }^{30}$ It is now clear that the hundreds of books and thousands of articles and tens of thousands of hours of oral history have been insufficient to steer the nation away from perhaps its most deeply ingrained conviction that 'we couldn't have been all that bad'. Only the older Aborigines who 'know it in their bones' and the bush workers, historians, linguists and anthropologists who understand it in their hearts, know just how terrible has been the early - and continuing history of the Indigenous people of Australia at the hands of the invaders.

Such a comprehensive rejection of Bringing Them Home and the Reconciliation Council's Final Report by a conservative government might have sponsored, as it did in Chile, a series of funas directed against individuals for committing crimes or acts of inhumanity or against government ministers for failing to punish them. Yet that seemed barely possible in an Australian context. The first obstacle, as we have seen, was the somewhat self-serving historical narrative accepted by the

29 John Howard, 'Practical Reconciliation', quoted in Grattan 2000, 88-90. The furthest that Howard moved towards acknowledgement of Indigenous injustice was 'And yet it is not possible, it is not possible for any of us, for any of us, to reflect upon the desirability of moving forward without acknowledging the impact that European civilization had on the people of this country and on the culture of the indigenous people. [We should] acknowledge the tragedies and sadness and the pain and the hurt and the cruelty of the past. To accept the ongoing trauma of that.'

30 Council for Aboriginal Reconciliation 2000. 
nation's citizens. Many Australians remain profoundly uninformed, unmoved or uninterested in the iniquities of the Aboriginal past, and certainly unprepared to accept a national narrative such as Canada's.

Secondly, Australian political culture was against it. The traditional Australian mechanisms of balancing competing interests have not anticipated reconciling deep-seated racial injustice. Unlike South Africa, no continuing Commission or Court exists to enquire into how and why Aboriginal people lost their land. ${ }^{31}$ The Racial Discrimination Act investigates uncontextualised cases brought by an individual against another individual. Australian mechanisms for public stability such as the former Wage Tribunal and Arbitration Court and Howard's Australian Workplace Agreements were developed out of British notions that the elements to be reconciled in society were those of capital and labour, worker and boss, not 'sectional' interests such as women's and Indigenous rights. Australian freedoms are the free speech of an individual, parliamentary privilege, and an impartial Governor General, or the collective balance between claims of state and federal government, or interest-based political parties. Historically these mechanisms have protected the nation well against the tensions they were intended to address.

Measures to protect Indigenous collective interests have been grossly inadequate, decisively unable to protect their interests, because the cultural legacy of the British did not anticipate that such divisions would ever arise in a British society and therefore would not need to be redressed. Chileans expect civil strife and the need for reparations, they utilise their established measures to re-stabilise the nation. By contrast, Australian governments have never admitted the wrongs they had inflicted on the Aborigines. They squirmed at the findings of Commissions or the High Court, and in the absence of established mechanisms, enacted few measures to confront what seemed to be irrefutable collective wrongs. Prime Minister Rudd apologised handsomely to the Stolen Generations but unaccountably offered no further measures of reparation. ${ }^{32}$ Many Native Title claims, while stoking bitter inter-family Aboriginal rivalries, remain mired in legal difficulties almost the equal of Jarndyce and Jarndyce in Charles Dickens' Bleak House. Aboriginal people enjoy very few of the ad-hoc Chilean measures informally and formally to achieve a modus vivendi after great trauma. ${ }^{33}$

\footnotetext{
31 See also Reynolds 2000: 56-57.

32 Again, Rudd's failure to consider such measures stands in strong contrast to measures adopted by the Canadian government, based on Boven 1996: 2 .

33 One of the few is the Indigenous Land Fund, which restores land to Aboriginal groups not through appropriation but by purchase from existing owners. It is close as Australians have come to the via chilena's 'one-off payments to sufferers on both sides of the recent conflict'. Other Chilean measures of conciliation include a memorial to a policeman killed by anti-Pinochet forces, state sponsored memorials to the disappeared at the former Santiago prisons of Villa Grimaldi, Jose Domingo Cañas and Londres 38, and whole-of-life pensions paid to families of the disappeared.
} 
Could Australians ever adopt that other interesting measure of the via chilena - the funa? The most spectacular expression of public disapproval of the government's position in the decade occurred as the Council of Reconciliation presented its Final Report in Sydney in May 2000. Australia's most senior Aboriginal public servant, Charles Perkins, sacked some years earlier from the Aboriginal Affairs Ministry, shouted at the Prime Minister in the packed Sydney Opera House, 'Say sorry you bastard!' Next day perhaps 300,000 people walked across the Sydney Harbour Bridge as a declaration of support for the Indigenous cause while a skywriter wrote the enormous letters of SORRY above them. ${ }^{34}$ The invitation had not been not cast as a castigation of the Prime Minister. ${ }^{35}$ Yet many saw it as an opportunity to punish him, for as the Chileans put it, 'as long as there is no justice carried out by the state, then there is the funa of the people'. While the Prime Minister was not stretched on his back like a cockroach, there was no doubting the intention or the intensity of the public denunciation. Perhaps Australia had achieved its first funa.

Chile had made its gestures towards reconciliation, and perhaps realists could have expected no better. Some Australians had higher hopes, but were disappointed. Yet reconciliation is more than present time. A less tense meeting of minds may well be possible in a generation or two in Chile when memories fade and records newly unsealed reveal how grandchildren of left and right may join hands to mourn together a hateful past. That can't be done without oral and historical records made as exhaustively and as fearlessly as possible shortly after the event. Thus Australians movingly reunited in 2000 at the site of the 1838 Myall Creek Massacre because plentiful records were collected at the time for the trial of the perpetrators. Many more Aborigines were killed at Waterloo Creek not far away in place or time, but because no proper investigation was carried, no reconciliation has ever, and probably never will, take place. ${ }^{36}$

Exhaustive historical enquiries are indeed essential both for the living victims of state violence and generations of the future who wish to reconcile. Perhaps we should not expect too much of them in the present.

\section{Acknowledgements}

I am grateful to Dr Marivic Wyndham for valuable comments on a draft of this paper.

34 See Sydney Morning Herald and The Australian, 27 May 2000; Gadigal Information Service, Aboriginal Corporation, 'Bridge Walk', <http://www.gadigal.org.au/GadigalInfo/Bridge_Walk.aspx?Id=6>

35 'On Sunday May 28 [2000] you are invited to join thousands of Australians on an Historic People's Walk for Reconciliation across the Sydney Harbour Bridge': 'Harbour Bridge Walk', pamphlet, Council for Aboriginal Reconciliation collection, AIATSIS.

36 Indeed, Aboriginal communities of the north-west of New South Wales rarely speak of it, and young people seem unaware of it; Serene Fernando, pers comm, 2009. 


\section{References}

\section{Primary sources}

Harbour Bridge Walk, pamphlet, in Council for Aboriginal Reconciliation collection, Australian Institute of Aboriginal and Torres Strait Islander Studies, Canberra.

van Boven, T 1996, Revised set of basic principles and guidelines on the right to reparation for victims of gross violations of human rights and humanitarian law prepared by Mr. Theo van Boven pursuant to Sub-Commission decision 1995/117, U.N. Doc. E/CN.4/Sub.2/1996/17, 24 May 1996.

\section{Newspapers}

The Australian

Sydney Morning Herald

\section{Secondary Sources}

Arditti, Rita 1991, Searching for Life, University of California Press, Berkeley.

Australian Human Rights Commission, Bringing Them Home, The Stolen Children's Report (1997), accessed 23 May 2010: <http://www.hreoc.gov.au/ social_justice/bth_report/index.html>

Carmona, Ernesto 2007, 'Detencion illegal de documentistas en Chile', Argentina Centro de Medios Independientes, 23 August 2007, accessed 23 May 2010: $<$ http://argentina.indymedia.org/news/2007/08/541832.php>

Clendinnen, Inga 2000, 'True Stories and What We Make of Them', in Essays on Australian Reconciliation, Michelle Grattan (ed), Black Inc, Melbourne: 242-253.

Commonwealth Parliamentary Debates, House of Representatives, 30 October 1996: 6158.

Council for Aboriginal Reconciliation 2000, 'Australian Declaration Towards Reconciliation', Corroboree 2000: Towards Reconciliation, accessed 23 April 2010: <http://austlii.edu.au/au/other/IndigLRes/car/2000/12/pg3.htm>

Council for Aboriginal Reconciliation 2000, 'Final Report of the Council for Aboriginal Reconciliation', Recommendation 6, accessed 20 April 2010: <http://www.austlii.edu.au/other/IndigLRes/car/2000/16/text10/htm> 
Council for Aboriginal Reconciliation Archive, Publications, Key 'Issues' papers, AustLII, accessed 20 April 2010: <http://www.austlii.edu.au/au/ other/IndigLRes/car/pubs.html\#publish>

Debelle, Penelope and Jo Chandler, 'Stolen Generation payout', The Age, 1 August 2007.

Gadigal Information Service, Aboriginal Corporation, 'Bridge Walk', May 2000, accessed 23 April 2010: <http://www.gadigal.org.au/GadigalInfo/Bridge_ Walk.aspx?Id=6>

Goot, Murray and Tim Rowse 2007, Divided Nation, Melbourne University Press, Melbourne.

Grandin, Greg and Thomas Miller Klubock 2007, 'Editorial introduction', Radical History Review, 97, Winter: 3-7.

Grattan, Michelle (ed) 2000, Essays on Australian Reconciliation, Black Inc, Melbourne.

- 2000, 'Public Opinion on Reconciliation', in Essays on Australian Reconciliation, Michelle Grattan (ed), Black Inc, Melbourne: 33-54.

Gunstone, A 2005, 'Unfinished Business: the Australian Reconciliation Process from 1991 to 2000', Journal of Australian Indigenous Issues 8(SeptemberDecember): 16-32.

Hayner, Priscilla 2002, Unspeakable Truths. Facing the Challenges of Truth Commissions, Routledge, New York.

Indigenous Law Resources: reconciliation and Social Justice Library, Royal Commission into Aboriginal Deaths in Custody, AustLII, 29 April 1998, accessed 23 May 2010: <www.austlii.edu.au/au/other/IndigLRes/rciadic/>

Lira, Elizabeth and Brian Loveman 2007, 'Truth, justice, reconciliation and impunity as historical themes: Chile, 1814-2006', Radical History Review 97: 42-76.

Nagle, Peter and Richard Summerrell 2002, Aboriginal Deaths in Custody, The Royal Commission and its Records, 1987-91, Research Guide no 2, National Archives of Australia, Canberra, accessed 23 May 2010: <http://www.naa. gov.au/naaresources/Publications/research_guides/pdf/black_deaths.pdf $>$

National Capital Authority nd, 'Reconciliation Place: A lasting symbol of our Shared Journey', National Capital Authority, Department of Families, Community Services and Indigenous Affairs, Canberra, accessed 23 May 2010: 
$<$ http://www.nationalcapital.gov.au/downloads/visiting/reconciliation_ place/Reconciliation\%20Place_A_lasting_symbol_of_our_shared_journey. $\mathrm{pdf}>$

Nolan, Mary, 2007 'The elusive pursuit of truth and justice', Radical History Review 97: 143-154.

Norman, Heidi 2002, 'An examination of the limitations of Reconciliation as a framework for Aboriginal social policy development', Journal of Australian Indigenous Issues 5(2): 10-17.

Read, Peter 1997, 'Pain, yes, racism, no. The response of non-British Australians to Indigenous land rights', in The Resurgence of Racism, G Grey and $\mathrm{K}$ Winter (eds), Monash Publications in History, 24, Monash University Press, Melbourne: 87-96.

- 2007, 'The Truth that Will Set Us All Free: National Reconciliation, Oral History 35(1): 98-107.

- 2009, 'Following the Funa: punishing the state in Chile', Arena Journal 32: $45-51$.

— and Marivic Wyndham 2008, 'Putting site back into trauma studies: a study of five detention and torture centres in Santiago, Chile', Life Writing 5(1): 79-96.

'Rettig Report', Wikipedia The Free Encyclopedia, 22 December 2009, accessed 23 April 2010: <http://en.wikipedia.org/wiki/Rettig_Report>

Reynolds, Henry 2000, 'A Crossroads of Conscience', in Essays on Australian Reconciliation, Michelle Grattan (ed), Black Inc, Melbourne: 53-64.

Royal Commission on Aboriginal Peoples 1996, People to People, Nation to Nation: Highlights from the Report of the Royal Commission on Aboriginal Peoples, Indian and Northern Affairs Canada, 11 March 2008, <http://www. ainc-inac.gc.ca/ap/pubs/rpt/rpt-eng.asp\#chp3>

'Rudd's apology to Indigenous Australia', The Daily Telegraph, 12 February 2008.

'Sir Ronald Wilson Should Apologise', accessed 23 May 2010: < http://www.ipe. net.au/nltr8.html>

The Funa of Victor Jara, 2007, video, Nèlida D Ruiz de los Paños and Christian R Villablanca (dirs), Parallel 40 and Televisió de Catalunya, Spain. 